\title{
"You Kind of Have to Bite the Bullet and do Bitch Work": How Internships Teach Students to Unthink Exploitation in Public Relations
}

\author{
Michelle Rodino-Colocino* and Stephanie N. Beberick** \\ *Penn State, University Park, USA, michelle@psu.edu \\ **Penn State, University Park, USA, snb182@psu.edu
}

\begin{abstract}
Based on critical analysis of three focus groups with PR students at Penn State, we argue that describing PR internships as "bitch work" highlights key material and ideological lessons about labour, gender, and exploitation. Analysing interviews of PR interns through Marxist and feminist perspectives, we explain the dynamics of viewing PR internships as "bitch work." We discuss how internships come to signify good luck in a lottery-like market while also instilling a love of work and the hope that "good work" will follow "bitch work." Such lessons, furthermore, teach interns to unthink work, our phraseology for the ideological process of viewing internships as almost-but-not-quite labour. We conclude with a call to rethink internships as work, recognize the gendered exploitation of interns, and compensate interns for their real labour.
\end{abstract}

Keywords: bitch work, college students, consolation, compensation, feminization, feminist critique, gender, ideology, internships, exploitation, free labour, hope labour, precarious work, public relations

Acknowledgement: The authors would like to thank Colleen Connolly-Ahern, Enica Castañeda, Bob Martin of the College of Communications at Penn State, special section reviewers and editors Enda Brophy, Nicole Cohen, and Greig de Peuter for their insights, and Isabel Fine for her editorial assistance. Thanks also to our audience and co-panelists at the Union for Democratic Communications conference in Toronto 2015 for feedback on an earlier draft of this essay.

"You kind of have to bite the bullet and do bitch work before you can work your way up the ladder, which is totally relevant in the PR industry" (Jessie, female senior Public Relations major). Jessie's assessment of her internship, shared during one of three focus groups we conducted at Penn State in central Pennsylvania with public relations majors who had previously worked as interns, serves as an apt description of the problem of internships. The essay explores how students conceptualize their labour as not labour but as "bitch work" that registers as close-to-but-not-quite exploitative. We also hope that the term "bitch work" can be appropriated as a rallying cry for collective mobilization against the exploitative aspects of internships.

To intern in public relations is to do "bitch work." Bitch work is the term one interviewee used and others expanded upon to describe aspirational grunt work undertaken as interns. Such language underscores interns' material and gendered exploitation, functions ideologically through distortion of such exploitation, and, through our appropriation of it here, offers a feminist critique of its material and ideological dimensions.

In public relations (PR), the field Jessie is studying, women make up 70-85 percent of the workforce below the executive level, whereas men make up 80 percent of upper management (Makovsky 2013). At Penn State, where Jessie attends school, 87 percent of Advertising/Public Relations (AD/PR) majors are women. Additionally, over three-fourths of unpaid interns in the US are women (Gardner 2011). According to three focus group interviews we conducted AD/PR majors enrolled in a PR course, women account for an overwhelming majority of unpaid internships. ${ }^{1}$ Our sample was 85 percent female (reflecting

\footnotetext{
${ }^{1}$ During the final week of the Spring 2014 semester we conducted three focus groups (of seven to 10 students each) that included 27 student interns (23 female and four male) who declared AD/PR majors in a PR course. The gender split parallels that in the major at Penn State. Participants were all juniors except for one senior. We
} 
enrolments in Penn State's AD/PR major), but women were even more disproportionately represented in the number of unpaid internships taken. ${ }^{2}$ Only one out of the 30 unpaid internships that participants listed in our pre-focus group survey was completed by a male student, whereas women worked in the remaining 29. Men, while comprising 15 percent of our sample, completed 30 percent of the paid internships. Over three-fourths of internships completed by students were unpaid (76 percent). ${ }^{3}$

Unpaid internships, however, do not seem to help graduates ascend career ladders. One national study finds that students without internship experience are only 2 percent less likely to receive a job offer than those who complete unpaid internships, and that those who complete unpaid internships are paid less in their first career-related jobs after graduation than those with no internship experience (Weissman 2013). Although the term bitch work connotes a feminized form of exploitation, both male and female undergraduates negotiate bitch work. As we explain in this essay, bitch work both names the gendered, exploitative realities of working as a PR intern and denies them.

Before proceeding it is worth considering the promise and pitfalls of centering the following critique around the term bitch work. For Jessie, bitch work constitutes grunt work that precedes the "good work" (Ashton and Noonan 2013, 5) that awaits her upon her ascent "up the ladder." Popular culture texts further elaborate on bitch work. As Urban Dictionary puts it, bitch work constitutes those tasks "given to lower level employees to keep them occupied for hours at a time, usually assigned by managers or higher level employees who are either too fat or lazy to complete the task at hand themselves." Putting a sexually objectifying spin on such language, Britney Spears' song "Work Bitch" asks, "You want a hot body? You want a Bugatti? You better work bitch. You want a Lamborghini? Sippin martinis? [...] Live fancy? Live in a big mansion? Party in France?" Jessie's and popular cultural notions of "bitch work," of course, derive from the derogatory word for "overbearing," "spiteful" women, to "lewd" or "immoral" women, and to female dogs ("Bitch" in MerriamWebster 2015). ${ }^{4}$ This essay, then, explores what it means to work like a "bitch."

The present essay puts Jessie's and the popular notion of bitch work into dialogue with our Marxist-feminist critical interpretation of the term. We critique bitch work by drawing attention to how the phrase works ideologically (as a cover or not-so-sweet-sounding euphemism for exploited labour) and materially as a descriptor of gendered exploited labour. Thus, we render the feminized aspects of "bitch work" visible. In so doing, we hope to appropriate the term as a feminist one as does Bitch Media, a feminist magazine, blog, and

recruited participants through a faculty colleague who announced the opportunity in an AD/PR majors-only PR class. Students participated for nominal extra credit points. All names have been anonymized-in place of students' real names we use pseudonyms suggested by participants. In all but one case, participants chose to express gender through a gendered pseudonym. In one case in which an interviewee selected a gender-neutral name, we asked if the student wanted to be perceived as male, female, or other (she wanted to be perceived as "female"). Focus groups ran approximately one hour and consisted of questions about what internships taught students. To initiate discussion, we asked participants to complete a short survey about their internship experiences. We also asked students to list the internships they completed and whether they were paid (and how much) or for credit (and in that case for how many credits). Survey and focus group questions are available from the authors upon request. Although interns found only four of the 48 internships they listed on their pre-interview survey through our College of Communication's internship office, we wanted to further contextualize our interviewees' experiences. To get a sense of the history of the program we interviewed Bob Martin, Dean of Internships and Career Placement. According to Martin's figures, the almost tenfold increase in the number companies listing internships with the office from $1999(450)$ to $2014(3,500)$ points to growing demands for intern labour. Martin expressed concerns about potential exploitation of interns and suggested that some form of monetary compensation for interns is warranted.

${ }^{2}$ These are the latest figures provided by the Advising Office of the College of Communications, October 27, 2014. Additionally, because we asked students to describe each of the internships completed during their college career, our list of paid and unpaid internships yields more internships than interns interviewed.

${ }^{3}$ Although these are not generalizable figures, they confirm findings of studies based on larger samples such as Gardner (2011).

${ }^{4}$ Merriam Webster Online, "Bitch," accessed July 15, 2015.

http://www.merriam-webster.com/dictionary/bitch. 
online media forum launched in 1996 as Bitch: Feminist Response to Pop Culture. ${ }^{5}$ Further, we agree with Bitch's editors that 'bitch' is an epithet hurled at women who speak their minds, who have opinions and don't shy away from expressing them, and who don't sit by and smile uncomfortably if they're bothered or offended." We hope that someday "bitch work" might gain traction in this way as a term for "talking back" as feminist media scholar Susan Douglas encourages readers to do (2010). At the very least, we hope that internship workers will understand and be able to discuss their exploitation as exploitation. We further hope interns will come to view their "bitch work" as a cause for collective political mobilization.

To explain how the PR interns we interviewed came to view internships as "bitch work" (but not quite as "exploitation"), we discuss how three smaller lessons teach interns that doing bitch work means not being a real employee who does real work. For interns, these smaller and often inter-related lessons also mean learning that internships signify good luck in a lottery-like market. Interns learn to "love" internships and learn to "hope" (Kuehn and Corrigan 2013) that internships will lead to the "good work" for which creative industries are celebrated (e.g. as work that yields personal satisfaction, happiness, and respectable pay; Ashton and Noonan 2013, Hesmondhalgh 2008). These three lessons teach interns to unthink work, our phraseology for the ideological process of viewing internships as almostbut-not-quite labour, and therefore not exploitable.

The following sections critically analyse each lesson as our interviewees described them. We attend to how these lessons may teach interns to unthink work by thinking about it as bitch work. We begin by discussing key theoretical concepts and our methodology. We conclude with a call to rethink internships as work, recognize the gendered exploitation of interns, and compensate interns for their labour. We hope that critical and feminist scholars of communication will work to eliminate the system that demands "bitch work" as a form of exploitation and utilizes it as a form of ideological cover.

\section{Exploitation, Ideology, and Feminization}

By "exploitation" we reference a more specific process beyond the word's connotative meanings of "use" and "to take advantage of." We apply Marx's (1876/2010) conceptualization of exploitation as it occurs through the extraction of surplus value in the labour process. According to Marx, surplus value is the ratio of "surplus labour" to "necessary labour." Socially necessary labour time is the amount of labour time it takes for workers to produce their wage. Surplus labour is the amount of time workers labour for the capitalist beyond the limit of necessary labour. The more surplus labour, the more surplus value workers produce. Surplus value may be increased by extending or intensifying the workday, thereby expanding absolute surplus value, or by shortening the amount of time it takes for workers to produce their subsistence, thus expanding relative surplus value. Relative surplus value increases as an effect of reducing the amount workers need to produce to cover living expenses, by devaluing labour power, or by making workers more productive for the wage they earn. "The rate of surplus-value," Marx argues, "is therefore an exact expression for the degree of exploitation of labour-power by capital, or of the labourer by the capitalist" (Marx $1867 / 2010,6)$. Thus workers may be exploited in multiple ways throughout their lives and differently according to their gender, race, class and a host of other divisions (Roediger and Esch 2012).

Without using Marx's terminology, the US Department of Labor (DOL) defines interns generally as "trainees" who, as opposed to workers, generate no surplus value for employers (United Sates Department of Labor 2010). Following Supreme Court precedent, one DOL fact sheet specifies "the term 'suffer or permit to work' cannot be interpreted so as to make a

\footnotetext{
${ }^{5}$ This feminist publication acknowledges that the term bitch may be "off-putting" to some people, but, they write, "we think it's worth it" because of the critical work the term does: "we stand firm in our belief that if we choose to reappropriate the word, it loses its power to hurt us" (About US 2015). We are, thus, in dialogue with Bitch's conviction about the critical potential of the term. First, by naming the problem of "bitch work," feminist and other critical communication scholars gain a useful conceptual tool for getting at the very kind of exploitation internships re/produce.
} 
person whose work serves only his or her own interest an employee of another who provides aid or instruction." More to the point, when a trainee's labour benefits employers, the DOL deems the trainee (intern) to be an employee. Putting it in Marx's terms, such interns, then, produce surplus value. Rates of unpaid interns' production of surplus value may be especially high compared to workers who earn income. Additionally, rates of surplus labour extraction are not consistent among industries that exploit interns. Some, especially men in the science and technology fields, are paid handsomely by internship standards prevailing in other sectors. Computer science majors in the US, 72 percent of whom upon graduation are men, reportedly enjoy the highest paid internships in the US, earning from $\$ 4,000$ to $\$ 7,000$ per month (Bort 2014; Miller 2014). Other interns, as essays in this issue of tripleC discuss, may earn no wages, sub-minimum wages, forms of payment-in-kind, or coverage of some costs of work. Additionally, some interns pay for their positions through college credits that cost tuition and registration fees.

Our ideological critique is attentive to both the real material exploitation of interning and the common sense that interns shared with us. We borrow Marx's concept of ideology to illuminate real material forms of exploitation. As interpreted by Michelle Rodino-Colocino (2012; see also Larrain 1991, 1996), Marx's concept of ideology describes the process of representing capitalist relations of production in ways that distort, and more specifically invert, such relations. These relations, furthermore, are inverted in reality. We explain ideology further below, but share one example for now: wages themselves are ideological as they make it appear to workers that they are paid for their time, when in actuality there is work time for which they are unpaid (i.e., "free labour" is an integral part of "paid labour" under the capitalist wage system). We discuss how lessons that internships teach make such ideological moves by rendering an already inverted material reality in ways that conceal, justify, and offer compensation and consolation for interns' exploitation. Without forgetting such real exploitation, we also argue that to understand the many layers of meaning "bitch work" signifies, we also need to "ask what is true," as Stuart Hall (1988) does when analysing the persuasive powers of Thatcherism. Here it is important to distinguish "true"-that which makes sense or rings true-from "truth," or that which refers to objective reality. "True," means "faithful, loyal, constant" and "in tune" (Oxford English Dictionary 2014). The hallmark of "true," Hall argues, is that it "makes good sense, which...is usually quite enough for ideology" $(1988,46)$. Conducting an ideology critique of internships means attending to both the "truth" and the "true" by considering how "bitch work" rings true and yet euphemizes the truth of exploitation.

Viewing internships as bitch work also points to the contention that the "new economy" demands the "cultural feminization" of labour (Adkins 2001). As feminist sociologist Lisa Adkins (2001) explains, the "cultural feminization" thesis holds that the post-industrialized First World requires workers to perform an "aesthetics of femininity" that attends to physical style and appearance (674). Linda McDowell (1997) finds evidence for the cultural feminization of work in interviews with financial workers. As Adkins (2001) argues, however, men and women are disparately rewarded for their feminine performances. Employees at one workplace interpreted men's feminine performance as springing from a skill set that merits reward, whereas women's feminine performance appeared as an unremarkable facet of their nature. Conservatives, meanwhile, have argued that today's job growth in the caring industries favours women, and thus, men should learn to be more feminine to compete (Perry 2008; Rosin 2010). Our interviews with undergraduate AD/PR majors find that the extent to which "bitch work" references cultural feminization (albeit not in such precise terms) illuminates a complicated set of gender relations caught between capitalism and patriarchy. Like Adkins, we argue that to the extent bitch work signifies exploitation, it should be contested. Additionally, as Madeleine Schwartz (2013) points out in her critique of internships, interns' free labour also mirrors the unpaid household labour women have long been expected to undertake (viewed as "helping" instead of as "work", paid by affective forms

\footnotetext{
${ }^{6}$ Below we discuss the six criteria the Department of Labour specifies as exempting interns from qualifying as "employees."
} 
of compensation).

The following three sections explore how interns come to view their labour as bitch work through the more narrow lessons of experiencing the internship market as a lottery, learning to love their internships, and hoping that bitch work indeed leads to good work. These lessons are intertwined, and at times one lesson leads to or supports another, as we explain in the sections below.

\section{Unthinking Work, Lesson One: Learning to View Internships as a Lottery Ticket}

The students we interviewed unthink work when they use language that describes the internships market as a lottery. As Nicole (who interned for a professional baseball team) describes her position: "it just made me feel really lucky because I was like, 'wow all of us are here because we are lucky'." Nicole's sentiments about "luck" suggest how competitive internship positions have become and what students are doing to find one. Vince boosts his odds of winning the intern lottery by blanketing the internship market with applications: "I applied to a bunch of places, too. I didn't really [get] anything. So I pretty much just took something local, like in my town." Similarly, Jill admits, "I probably contacted, like, literally 75 places and none of them responded, and the one I ended up getting was from a list from a club l'm in."

Anxiety about the future job market is palpable in the words of some interviewees like Nicole, who describes internships as a lottery ticket of sorts. Nicole expressed concern about companies like Condé Nast that eliminated its internship program during a class action lawsuit because, "if all of these awesome internships with these cool companies... say 'screw it', we just won't have interns." Consequently, an already tight contingent market will grow impossibly tighter, she explains. For Nicole, landing an internship is the prelude to landing a job, and thus, the internship position itself serves as a ticket in the job lottery-a chance to compete with the "hundreds of thousands of people just like us." The odds are steep. As she attests, despite her personal connection at the baseball team, Nicole applied for over 100 internships and was offered three. She chose to intern for the professional baseball team at $\$ 9.50$ per hour. Thus, Nicole describes herself as "lucky," especially after working as an unpaid intern in the retail fashion industry.

To boost their odds of getting an internship, interviewees combine the quantitative strategy Vince and Jill describe with the qualitative strategy of calling in personal connections. Nicole used a family connection to land an internship. Competition for any internship, let alone a "cool job" in a "hot industry" (Neff, Wissinger, and Zukin 2005) like professional sports is so intense that personal connections were described as even more important. Nicole thought her tactics were unique but soon learned they were hackneyed. As she says, "every single intern knew someone even more important than I did." Personal connections begat an internship for Elena: "I got my internship because I knew two people who worked at the PR firm that I worked at..." Summing up the importance of such connections, Elena concludes, "I don't know, I just think it all comes back to who you know." Jill agrees:

It's all because I know someone. And like I said it's becoming more and more the prominent thing. It's so much more competitive. Like, if you come out of college and you don't know anyone you're kind of screwed. And l've seen it more with the bigger companies... with the big name you need to know someone.

Thus personal connections, especially to an "important" person at a "bigger," "big name" company, increase the odds of landing "hot" internships in "cool" industries that advertising/PR majors seek. Internships, in turn, increase the odds of producing key personal connections. As Ross Perlin (2012) tersely puts it, "If personal connections grease the wheels of the job market, they are the motor powering the trade in internships" (165).

Understood in this way, internships also signify a classed and more subtly raced and gendered achievement. As David Lee (2013) argues, the importance of personal connections 
underscores the very social exclusivity of internship labour in high status fields that are attractive to students from middle-class professional families. Personal connections both signify class achievement and help reinforce it through the process of landing internships.

Jessie, who describes internships as "bitch work" recalls her reaction to the College of Communications' PowerPoint presentation:

[Y]ou should have four internships before you graduate. And I was like, "four?" That means I'll have to have one like every summer in between now and my senior year. One during the school year-or two [...] And I was like, how is that even possible? I remember last year, I applied so many places and it's so competitive. And taking something that was part time and unpaid and I just [...] some days I sat there and said "why am I doing this?"

Conversations we had with interns revealed a great deal of contradiction in students' perceptions of internships as means to improve their odds of landing future work, proving that in addition to the specific lessons internships teach it is difficult to nail down interns' own perspectives on their internship labour. One conversation turned from the greater anxiety students experienced about landing internships than landing jobs (Sarah shares, "I feel like I was more worried about not getting an internship than I am about getting a job") to the idea that one's college degree improved one's odds greater than did internships in the great career lottery. As Frank (a participant who wishes to be identified as female but chose a traditionally masculine pseudonym) responds to Sarah's concern, "I think that, like you said, [l am] more worried about getting an internship than getting a job." Frank explains, "I think that [concern] comes from the fact that we're so conditioned to feel that if we don't have an internship we're going to fail miserably at life and never get a job." Then Frank turns that logic around by arguing against the very necessity of internships and instead for the value of formal degrees, "Everyone feels like they need sixteen [internships] at a time, and we're also are more afraid of not getting internships than not getting jobs because once you have a degree, you are probably going to get a job." Thus, Frank describes the job market as competitive, but her university degree-not her internship-is the ingredient that in the last instance increases her odds of landing a job. In this way, Frank argues against the notion of internships as aspirational, lucky-to-get bitch work that improves chances of finding postgraduate paid work in the great career lottery.

We also want to flag that the notion of "bitch work" co-exists with other gendered language around internship labour. Frank prefaces her back-and-forth discussion of internships as lottery tickets and ends in themselves through masculinizing language she uses to describe pressure from her parents to find an internship:

Like I remember in February I went home for a weekend [and] my parents were busting my balls because I didn't have an internship in the summer. I was like, 'Dude, it's February!' So I immediately went back to school and started to apply for stuff and then I got something.

We find it significant that before conceding that a college education increases odds of landing future work more than do internships, Frank masculinizes herself ("busting my balls") and her parents (whom she collectively calls "dude"). Frank casts her active pursuit of an internship in the well-worn masculine mantle of seeking paid work as a breadwinner.

Although internships figured as lottery tickets to improve labour market odds, interviewees did not describe them as the kind of work or labour that is covered by US minimum wage laws. It is worth emphasizing the importance of Marx and Engels' (1996) argument that ideology operates like a "camera obscura" that turns real life phenomena on their heads. Interviewees are not merely imagining the long odds of landing internships; these odds exist in material reality. Nor are they alone, as students working in creative industries beyond advertising and public relations can attest (Hesmondhalgh 2010; Neff, Wissinger, and Zukin 2005). Discussing the internship and labour markets as lotteries of sorts, based on "luck," denies, or rather, unthinks the work they do as interns. It also glosses over the class privilege that interns mobilize to land such positions and the gender 
discrimination they will continue encounter-if the predominance of men in upper management is any indication-as public relations professionals. We are concerned that such logics prepare interns to endure bitch work instead of resist it.

For interviewees, therefore, internships did not feel exploitative in the Marxist sense. The interns we spoke with viewed their exploitation in an inverted way as a boon rather than as exploitation. Internship and job markets are highly competitive, however. Thus in today's contradictory and exploitative capitalist labour force, interns have reasons to feel "lucky" to work for free (or little, or at cost to them) in positions that may not guarantee future work and instead train them to expect low wage, precarious employment. Interviewees' discussion of internships, furthermore, suggests that the real (not false) competition for the positions combined with the (real) training received and (real) enjoyment experienced makes interns feel compensated. As Kira puts it,

You get paid kind of in knowledge and experience...in PR, in advertising, and communications in general, there's a 150 people who want the position that you have. So I think that you may not be getting paid, but if you're working a nine to five job where you love it and you're getting actual experience-things you can put in your portfolio, things you can talk about in a real job interview then you are kind of being paid.

Understood through the lens of Marx's ideology critique, internships provide consolation and justification for the creeping sense of exploitation that Kira experiences but does not explicitly recognize. Nor is Kira alone.

Sarah comes the closest to calling her unpaid internship exploitative, but then backs away by recourse to the internship-as-lottery theme:

I still think they [the company] made us do a lot more like [...] not exploit us, but they definitely had us do a lot and it's not like they don't have any money. So I don't understand why they didn't even pay us $\$ 8$ an hour.

As she equivocates, Sarah further illustrates the process of unthinking the work she is doing by expressing the luck and gratitude she feels in landing the position:

I don't want to say exploited because they did give me valuable experience. I applied to so many internships and this one, I was so lucky to get an interview with them because I didn't know anyone and a lot of people were there who did. I don't want to go and trash talk them, I just feel bad. They did give me such valuable experience.

Interns are not necessarily being duped by the enticement of winning the lottery or the promise of immaterial benefits, but they are being exploited. Interviewees may not experience their internship labour as labour and as exploitation, but the mechanism for their consent comes from the ways interns are taught to view (and emotionally experience) their internships. Another key lesson interviewees learned is to love their internships.

\section{Unthinking Work, Lesson Two: Learning to (Love) Labour}

Feeling compensated beyond wages (and credits) enables interviewees to think about internships as not work. ${ }^{7}$ But here lies a contradictory belief interns hold: hard work can indeed be its own reward, but what interns do is not necessarily experienced as "real work." Interns learned to love their internships. Loving their internships helps interns believe that their efforts are not worthy of pay and therefore do not constitute labour. Here Paul Willis' (1977) critical ethnography of working class lads is illuminating. Learning to Labour shows how working-class schoolboys participate in creating a culture where their manual labour (as opposed to white-collar, middle class labour) is expected, even if they resisted such expectations in some ways. Visiting factories where the boys would one day work, Willis

\footnotetext{
${ }^{7}$ Many of the interns we spoke with preferred doing not-for-credit internships during the summer so that they could avoid paying registration fees.
} 
observed a "masculine chauvinism" in shop floor culture. Families and schools taught this ethos to the lads, despite the rebelliousness they performed within their social groups. Thus, the lads were also engaged in ideological work that reflected and affected their working class status. Willis calls this process "learning to labour."

Instead of finding masculine chauvinism that teaches students to labour, we find that among interns we interviewed, learning to love labour reflects a cultural feminization. The cultural feminization of labour is not new, however. Loving one's labour has long justified women's free familial labour and helped represent such labour as not really (i.e., not productive) labour. Silvia Federici made the point poetically in 1975, "They say it is love. We say it is unwaged work" (Federici 2012; see also Fortunati 1996). Or as Giovanna Dalla Costa (2010) explains, the "ideology of love" whereby women in industrialized capitalism are taught to do unpaid work for family members (and above all, husbands) in exchange for "love" casts women's free domestic labour as "a labour of love" (location 253). It is really women's free labour that is being exchanged in what Dalla Costa describes as "the heaviest of ideological mystifications imposed on a labour relation" (location 253).

Women have been working under such relations since the mid 19th century in developed industrial capitalist countries.

Recognizing this history is especially helpful to account for how PR interns, most of whom are women, come to unthink labour through love and explains how such love may reproduce gender inequality in the field's intern and labour markets. PR as an industry demands women's emotional labour to such an extent that even female PR executives view the distinctive qualities required by the work as springing from women's natural essence (Pan 2014). As Arlie Hochschild (1983) argued over thirty years ago, learning to love work and working with a smile constitute emotional labour, a kind of work that is increasingly expected of women as paid employees. "Pink collar" workers, women working as flight attendants, secretaries, sales clerks, and PR professionals, for example, not only "sell" their personalities as C. Wright Mills (1915) discussed, but they perform the labour of showing their love for their work and indeed, loving their labour (Pan 2014). As early as the 1920s when 50 percent of secretaries in the US were women (Hesse-Biber, Nagy, and Carter 2000), they began figuring in management texts and popular culture as "office wives" who served as extradomestic spouses and sexual objects of desire (Davies 1982; Marcellus 2006). Scholars' attention to the "immaterial labour" (Hardt 1999; Lazzarato 1996) through which workers produce appropriate affect has extended interest in these questions, and is part of the broader "affective turn" of critical labour and sociological studies (Clough and Halley 2007). ${ }^{8}$

The ideological work of learning to love intern labour, as it has long operated for women as paid and unpaid workers, may help our interviewees unthink their intern labour as human power that produces surplus value (Marx 1867/2010) and, in the legal sense, as falling under the regulatory purview of the US Department of Labor. Like factory men imbued with a sense of masculine self-esteem attributed to their hard work well done (Willis 1977), Crystal's love of her internship springs from the pride she takes in the long hours she dedicated to her unpaid work for a fashion magazine:

Even though you're supposed to work from nine to five, it's not a nine-to-five job. It's really whenever you finish a job; you do it well. I would stay well past $5 \mathrm{pm}$ and leave with a smile on my face, and it wasn't just me. It was all the interns all the [time]. It just it sucks when it's summertime and you leave at $8 \mathrm{pm}$, but you do with a smile on your face and you are getting the job done and we had a great product and it's worth it.

"Getting the job done," in Crystal's description, made her so happy that she told us twice that

\footnotetext{
${ }^{8}$ While loving one's work serves as a labour discipline integral to a new economy dependent on image-selling (Gregg 2011; Wissinger 2007), we also recognize that encouraging internalized labour discipline has a longstanding history. Industrial managers overseeing male factory workers during the Progressive Era in the US from 1890-1920 wanted workers with "the type of discipline which wells up from beneath and is at least partially self enforcing" (Haber 1964, 130).
} 
her long work hours left her with a "smile on her face." Despite the lack of self-care brought on by long hours and tight deadlines, Crystal completed such work with a smile on her face because she had produced a "great product." Similarly, Frank states that, "Internships are absolutely essential to our happiness in life so that's why [...] it's so competitive to get an internship."

Nevertheless, it is also possible to read ambivalence in such statements. Happiness may indeed be seen as a form of payment when interns enjoy the work. Domingo alternates between happiness and dread (caused in part by parental pressure to find an internship) when describing his feelings during the internship application process:

I really put my focus into the places that I want to work, and my whole thing is like, I am not very concerned about the pay or whether it's paid or unpaid. It's just, I want to enjoy every second of what I'm doing. So I applied to a lot of places that would give me the opportunity to do that, but I know there's places that I applied to that I like would not even want to work there at all.

Domingo suggests here that compensation is of no consequence. Payment need not be exchanged for labour if he enjoys it. Domingo also demonstrates how compensation may take forms other than wages for interns, who in turn learn what to love about their work.

Interviewees' love of internships also springs from a sense that classes do not fully prepare them for future employment. This sentiment echoes critical scholarship on higher education and internships (Berger, Wardle and Zezulkova 2013; Lee 2013). Students like Kira value internships for teaching job-ready skills. An unpaid internship for a fashion magazine taught Crystal "what I really needed to learn for the job." As she puts it, internships prepared her to enter the workforce in PR "better than any of my classes." Other interviewees elaborated on the value of specific skills they learned. Kira appreciates learning "all the different parts of corporate PR," both "external" and "internal," right down the details of "doing... recruitment pitches for STEM [science, technology, engineering and mathematics] like how to get more kids into STEM and more [female] engineers." For Domingo, who worked with a university athletics department for one credit, "the biggest thing I took away is just to learn how to be a networker just in your everyday life." Watching his boss offer rides to new students, take people to lunch, and be available for his clientele taught Domingo that "Just really being connected with as many different people as you can...I think that's...the biggest thing I took away from the internship." Jessie is grateful for her unpaid internship because she "learned a lot about media planning [and] placement that I had not learned before." The most valuable thing Jessie learned was "responsibility," by which she meant, "taking charge of researching...interviewing, and showing up for work every day." "That type of experience," Jessie adds, "you don't get in the classroom."

Jessie, Domingo, Crystal, and Kira appreciate that form of compensation-training-that distinguishes "interns" from "employees." After all, gleaning knowledge and skills helps constitute the legal definition of internships as nonwork, and thus as training that is exempt from federal regulations and minimum wage laws in the US. As students gaining job training, interns are supposed to learn job-ready skills that their classes do not provide. As the DOL's Field Operations Handbook (FOH) specifies, "training is for the benefit of the trainees or students." To be exempt from minimum wage laws, moreover, internships must meet all six criteria outlined in the $\mathrm{FOH} .{ }^{9}$ Based on our focus group discussions, the criterion that internships fail to accomplish is the fourth, in which "the employer that provides the training derives no immediate advantages from the activities of the trainees or students, and on

\footnotetext{
${ }^{9}$ The US Department of Labor has determined that unpaid internships must meet all six unpaid internships must meet all six requirements: (1) the training, even though it includes actual operation of the facilities of the employer, is similar to which would be given at a vocational school; (2) training is for the benefit of the trainees or students; (3) the trainees or students do not displace employees; (4) the employer that provides the training derives no immediate advantages from the activities of the trainees or students, and on occasion operations may be actually impaired; (5) the trainees or students are not necessarily entitled to employment at the conclusion of their training period, and, (6) the employer and the trainees or students understand that the trainees or students are not entitled to wages during training (United States Department of Labour 2013; see also Perlin 2012, 66).
} 
occasion operations may be actually impaired." No matter how well-compensated students actually are in terms of training, no matter how deeply interns believe that the training they receive makes up for gaps in their education, by law a "trainee" becomes a "worker" who is due wages when an employer enjoys "immediate advantages" from the internship. Thus, interviewees' appreciation of the training offered through particular internships points not to their false consciousness about their exploitation but to the real conditions that enable it. As Perlin (2012, xiv) puts it, internships constitute "mass exploitation hidden in plain sight."

Such sleight of hand is possible because interns learn to love their labour, and further, because some interns feel loved by those for whom they labour. Such love is further justified, as our interviewees explained, because they come to believe that their bosses care about their welfare. Crystal, who interned for a corporation that faced a class action lawsuit for its unpaid internship program explained that the recent spate of interns' lawsuits may lack merit:

I didn't feel exploited because, sorry if I did stay late, like I said, if we had to work late hours, they did buy us dinner, and it wasn't like they didn't care about us. My boss... invested in me and she knew that I was commuting from Long Island so if I needed to leave a little earlier than some of the girls who were living in NY dorms, I could.

For Crystal, payment in kind/ness served as an acceptable substitution for wages. It is also telling that Crystal references a caring community where her co-workers are "girls" who live in dorms and her boss is a woman. Does Crystal take for granted this feminized work community, given the feminization of public relations? Would she have perceived the boss's concern for her as caring had her boss been a man? As Adkins (2001) suggests, male workers who engage in feminized work performances are more likely to be rewarded than are women. Women's caring labour is overlooked as an essential trait of femininity (thus not deserving of promotion or higher pay when women perform it). Does Crystal's boss, then, get paid materially for her empathetic treatment of her workers? These questions suggest lines for future research.

Nevertheless, this sense of belonging to a female work community that cares about individuals gets at what Hector Postigo (2009) calls "passionate labour" in his study of the making and unmaking of such labour among AOL volunteers. As Postigo notes, potential for challenging that passion is ever-present in working conditions that are exploitative but do not "feel" that way. Confirming Postigo's findings, interviewee Parker maintains that she is "really passionate" about the interns' lawsuits; she finds unpaid internships to be "ridiculous." She further faults unpaid internships as "the bullet you have to bite" so that it "will all be worth it." Interviewees, moreover, imagine future gain to explain present exploitation as something else. Kathleen Kuehn and TC Corrigan (2013) call working in anticipation of future reward "hope labour," and it serves here as a key ingredient in unthinking work.

\section{Unthinking Work, Lesson Three: Got Hope (Not Exploitation)?}

As Kuehn and Corrigan $(2013,10)$ conceptualize it, hope labour is that "un- or undercompensated work carried out in the present, often for experience or exposure, in the hope that future employment opportunities may follow." Working for hope provides a feeling of immediate pay: although interns understand they are deferring material pay and security, they maintain hope in the present for a better future. Hope labour, therefore, provides ideological compensation and consolation. For our interviewees, a pervasive sense of hope seemed to make up for, if not displace, a sense of exploitation. Without recognizing the labour they did or the surplus value they created, the students we spoke with hoped their internships would make them attractive job applicants. Rachel explains how a combination of hard work and recognition of self-improvement for a future job served as compensation in unpaid internships at one Chamber of Commerce and athletics department,

I think especially taking initiative and going the extra mile and doing things beyond what you're expected. Like they really take notice of that and, like, take that to heart and know, like, you're not just there for an internship. Like you really are invested in making yourself 
better, a better person for the future and helping their company or whatever organization you're working for.

Here Rachel expresses the importance of showing future employability through hard work that registers with employers. Rachel's hard work is, furthermore, performative: it demonstrates being "invested in making yourself a better person for the future." Like the AOL workers Postigo studied, Sarah learned to appear "really passionate and [to] conduct yourself well" to gain an advantage over other job applicants "by the time you get to that real interview process." Rachel and Sarah hope that their internships provide advantages in "the future" and in "that real interview process." For them lessons learned about loving labour and being "passionate" about it underwrite hope labour.

Bitch work is necessary grunt work interviewees endure because it improves their résumé and thus hopefully increases the odds of finding work after graduation. As Frank explains, "[W]e don't have a choice. It's either take these kind of grunt work internships for absolutely no compensation or have nothing on your résumé and never get hired." Guy, the male student in our sample who completed an unpaid internship, adds that playing for the future is an understandable strategy: "Well the way I see it, you take the unpaid now; I mean it's justifiable. Take the unpaid now for further experience, and then when you come out of school that's when you really go for the job you really want." In other words, if postgraduate jobs are "real," internships by comparison are not.

Furthermore, hoping for a better job ideologically distorts the exploitation interns experience by making internships feel like not-quite-real labour, as a liminal but not quite exploitative experience. Describing the online free labour of Yelp.com posters and sports bloggers on SB Nation, Kuehn and Corrigan (2013) argue that "[h]ope labour functions because it is largely not experienced as exploitation or alienation, despite the commodification processes inherent to digital and cultural production" (12). Hope may nudge Yelpers, bloggers, and intern labourers into feeling their work as not real work and thus, as not possibly exploitative. For Jessie the telos of her "bitch work" was landing a $\$ 22 / \mathrm{hr}$. plum internship that she calls a "job." When we asked her to specify whether this position was a job or internship, Jessie answered, "It's an internship that hopefully will be leading to a job."

Hoping that bitch work will one day lead to paid work, interviewees communicated ambivalence about whether interns should sue employers for being exploited as free or cheap labour. ${ }^{10}$ When asked if they thought the recent spate of class action lawsuits in the US against interns' employers had merit, Cecily explains,

I feel like there's a really big fine line between like exploitation and just like you're not getting the right amount of compensation. And I feel a lot of these lawsuits are about the interns want to be paid like they're actual employees. But we don't have our degree, so it's kind of ridiculous to ask for that amount [...]

Cecily locates the "really big fine line" between "exploitation" and "you're not getting paid the right amount of compensation" by considering the presence of harm. Far from supporting the lower threshold for exploitation that the Department of Labor applies, Cecily argues, "I feel like I would only file a lawsuit if I was actually seriously being harmed in some way. Like if it were really big." Although she does not specify how she may be harmed, she emphasizes the damage would have to be significant for her to sue her internship employer. Rachel agrees and articulates a lack of harm with presence of training, hope, and luck:

[I]f you're not being harmed and you're being treated [respectfully], and you're learning things from these people that's going to help you more in the long run than being paid $\$ 10$ an hour. Like, that money's going to go out the window anyway. So just be thankful that you have an internship that a lot of people would be looking for.

\footnotetext{
${ }^{10}$ See Daniel Miller's (2014) discussion of class action lawsuits that were being reported in the media around the same time as our focus group interviews.
} 
Nadia echoes Rachel's views, citing the temporary nature of internships that also promises upward mobility:

\begin{abstract}
Yeah I agree with that. Because I feel that people forget that an internship is supposed to be a learning experience. It's not supposed to be your job. Like you're not going to be there for the rest of your life. You're there for the summer to learn about the company or the work that it does or if that's like the work that you want to be in. I think people forget that it's supposed to be a learning experience [...] [T]hat's where, like, the boss starts. The boss did that once.
\end{abstract}

The boss, Nadia proposes, started their career as an intern, thus Nadia has reason to hope for such upward mobility in her PR career. Allison calls this "a benefit in the negative of internships."

Other interviewees' ambivalence about deeming internships to be exploitative connects the three smaller lessons that teach the broader ideological lesson of viewing internships as bitch work that precedes real, good work. According to Kira,

I think if it is something where they are making you run rampant and get food for the office-and I kind of think Devil Wears Prada, like Andy—but not getting paid, not a full time employee, like, being treated poorly by your boss and not being treated like a person, then that's something where you might want to take legal action. [...] But I think that it is a very fine line. We're in college and times have changed and there's even post grad internships now for agencies. You leave college. You have a degree and they're still going to pay you $\$ 10$ an hour in an agency and call you an intern because they can because this industry is getting so competitive. And so popular that they can do it, and as long as you are getting something real out of it I don't think it's necessarily exploiting them.

Instead of portending further exploitation in the job market, postgraduate internships signify the reality of heightened competition and thus low pay. Kira looks at one of the six criteria the DOL lists as necessary for exempting pay as the one that precludes interns from being exploited. While this perspective does not extend as far as that of the DOL, it seems to ring true among interviewees who do not see internships as exploitative. Borrowing the language of hope labour to communicate ambivalence about the highly competitive media industries of sports and fashion, Parker explains:

You know everyone like wants to be in the industry whether it be like sports or just like being in New York or fashion, whatever. They're so competitive that someone's going to take it whether it's you, or when you walk away, someone else. So yeah, it makes me really mad. But $[\ldots]$ hope it pays off.

Parker is "mad" and yet "hopeful." She is mad at the thought of not getting paid for her work but hopeful that the unpaid work will pay off in the future by helping her find work in the media industry of her choice. Thus, the bitch work in which interviewees engage as interns also works like the "aspirational labour" Brooke Duffy (2015) describes in her study of female digital cultural producers in beauty, fashion, and retail. These workers combine the second and third lessons we discuss here by engaging in "productive activities that hold the promise of social and economic capital" and promise the more immediate payoff of "doing what you love" (1-2).

Thus, internships do pay. They do compensate and console in the way that ideology does. Most of the internships discussed by our interviewees, however, did not pay materially in the present, even when interns engaged in enjoyable tasks. In this way, internships teach ideological lessons as they exploit labour in Marx's sense of the word and according to the US Department of Labor.

\title{
5. Conclusion
}


Our public relations students view internships as the bottom rung on a ladder constructed by bitch work and made bearable by hope, love, and luck. Such a view enables them to unthink work, and with it their exploitation as workers who produce surplus value. Therefore, we propose that critical scholars of communication intervene in the ideological work of internships and the exploitation they enable.

First, we should encourage our students to rethink work. We find it significant that at the end of each focus group when the recorder was off, participants discussed a sense of relief in finally giving voice to pent-up frustrations around internships and future employment. Students are ready to have such conversations. Public relations courses, job preparation seminars, and campus internship offices should inform students of their rights as workers. At the very least we should make the laws governing work accessible to students. More than this, however, we can help them understand the law. Furthermore, in an atmosphere in which higher education instructors feel pressure to train job-ready students, we should not abandon our ethical responsibility to prepare labour-force-ready graduates. By this we mean preparing students to respond to unethical and illegal exploitation of their labour as interns. We should also become engaged in policy building around internship labour. Penn State's Bob Martin, our head of internships and career services, suggests paying interns. We agree that paying interns is warranted (legally and ethically), and we support compensation for interns when they are engaged in work that provides "immediate advantages" to employers, as the US Department of Labour requires. We advocate debate around how to pay and when to pay interns as employees. Additionally, we should share feminist and Marxist critiques of labour and bitch work in the classes we teach. We want to challenge ourselves and our students to interrogate "bitch work" as symptomatic of patriarchal and capitalist exploitation.

The term is, furthermore, ripe for appropriation as a rallying cry for collective mobilization. Much as "sweatshop labour" names the exploitation of un- and under-paid, overworked workers who make university logo memorabilia, "bitch work" can so name that labour that universities tacitly and often publicly endorse. Additionally, we hope that "bitch work," like "sweatshop labour," enters the campus social movement lexicon and inspires action, challenge, and change. As the editors of Bitch Media intend for their audience, we hope that tripleC's readers-as academics who may supervise student interns and promote internships more broadly - will cease to "smile uncomfortably if they're bothered or offended" by the exploitation they witness or hear about when teaching and advising students. We want readers to work for the day when we can say (borrowing from Bitch), "if being an outspoken [worker] means being a bitch, we'll take that as a compliment" (About Us 2015). We want readers to join with interns in "bitch sessions" that collectively mobilize workers in effecting systemic change. Then we may turn our inverted relations of production upside-up, spreading the benefits among those whose labour creates the very industries students hope they are lucky enough to love.

\section{References}

About Us. 2015. Bitch Media. Accessed May 14, 2015. http://bitchmagazine.org/about-us. Adkins, Lisa. 2001. Cultural Feminization: "Money, Sex and Power" for Women. Signs 26 (3): 669695.

Ashton, Daniel, and Caitriona Noonan. 2013. Introduction: Cultural Work and Higher Education. In Cultural Work and Higher Education, edited by Daniel Ashton and Caitriona Noonan, 1-24. Palgrave New York: Macmillan.

Berger, Richard, Jonathan Wardle and Marketa Zezulkova. 2013. No Longer Just Making the Tea: Media Work Placements and Work-Based Learning in Higher Education. In Cultural Work and Higher Education, edited by Daniel Ashton and Caitriona Noonan, 87-109. New York: Palgrave MacMillan.

Bort, Julie. 2014. 7,000 A Month! Look at the Incredible Salaries Summer Tech Interns Are Earning. Business Insider, June 29. Accessed December 2, 2014. http://www.businessinsider.com/insanesalaries-for-tech-interns-2014-6?op=1\#ixzz3IIPValGr.

Clough, Patricia Ticineto and Jean Halley, eds. 2007. The Affective Turn: Theorizing the Social. Durham: Duke University Press. 
Dalla Costa, Giovanna Franca. 2010. The Work of Love: Unpaid Housework, Poverty and Sexual Violence at the Dawn of the 21st Century. Translated by Enda Brophy. New York: Autonomedia. Kindle.

Davies, Margery W. 1982. Woman's Place is at the Typewriter: Office Work and Office Workers 18701930. Philadelphia, PA: Temple University Press.

Douglas, Susan. J. 2010. Enlightened Sexism: The Seductive Message that Feminism's Work is Done. New York: Times Books.

Duffy, Brooke Erin. 2015. The Romance of Work: Gender and Aspirational Labour in the Digital Culture Industries. International Journal of Cultural Studies. Accessed May 14, 2015. Online first at: http://ics.sagepub.com/content/early/2015/02/25/1367877915572186.full.pdf+html.

Federici, Silvia. 2012. Wages Against Housework. In Revolution at Point Zero: Housework, Reproduction and Feminist Struggle. Oakland: PM Press.

Fortunati, Leopoldina. 1996. The Arcane of Reproduction: Housework, Prostitution, Labour and Capital. New York: Autonomedia.

Gardner, Phil. 2011. The Debate Over Unpaid College Internships. Austin: Intern Bridge.

Gregg, Melissa. 2011. Work's Intimacy. Cambridge: Polity Press.

Haber, Samuel. 1964. Efficiency and Uplift: Scientific Management in the Progressive Era 1890-1920. Chicago: University of Chicago Press.

Hall, Stuart. 1988. The Toad in the Garden: Thatcher among the Theorists. In Marxism and the Interpretation of Culture, edited by Cary Nelson and Larry Grossberg, 35-58. Urbana: University of Illinois Press.

Hardt, Michael. 1999. Affective Labor. Boundary 226 (2): 89-100.

Hesmondhalgh, David. 2008. Cultural and Creative Industries. In The SAGE Handbook of Cultural Analysis, edited by Tony Bennett and John Frow, 552-569. Thousand Oaks: Sage.

Hesmondhalgh, David. 2010. User-Generated Content, Free Labour and the Cultural Industries. ephemera: theory \& politics in organization 10 (3/4): 267-284.

Hesse-Biber, Sharlene Nagy and Gregg Lee Carter. 2000. Working Women in America: Split Dreams. New York: Oxford.

Hochschild, Arlie. 1983. The Managed Heart: Communication of Human Feeling. Berkeley: University of California Press.

Internship PowerPoint. Accessed June 18, 2014. http://comm.psu.edu/career-services-andinternships.

Kuehn, Kathleen and Thomas F. Corrigan. 2013. Hope Labour: The Role of Employment Prospects in Online Social Production. The Political Economy of Communication 1 (1): 9-25.

Larrain, Jorge. 1991. Marxism and Ideology. Vermont: Gregg Revivals.

Larrain, Jorge. 1996. Stuart Hall and the Marxist Concept of Ideology. In Stuart Hall: Critical Dialogues in Cultural Studies, edited by David Morley and Kuan-Hsing Chen, 47-70. New York: Routledge.

Lazzarato, Maurizio. 1996. Immaterial Labour. In Radical Thought in Italy: A Potential Politics, edited by Paolo Virno and Maurizio Lazzarato, 133-147. Minneapolis: University of Minnesota.

Lee, David. 2013. Creative Networks and Social Capital. In Cultural Work and Higher Education, edited by Daniel Ashton and Caitriona Noonan, 195-213. New York: Palgrave MacMillan.

Makovsky, Ken. 2013. Women in Leadership in PR. Forbes, February 25. Accessed December 2, 2014. http://www.forbes.com/sites/kenmakovsky/2013/02/25/davos-blog-1-women-in-leadership-inprl.

Marcellus, Jane. 2006. Women as Machine: Representation of Secretaries in Interwar Magazines. Journalism \& Mass Communication Quarterly 83 (1): 101-115.

Marx, Karl and Frederick Engels. 1996. The German Ideology. Edited by C.J. Arthur. New York: International Publishers.

Marx, Karl. 1867/2010. Capital: A Critique of Political Economy, Vol. I. Accessed October 31, 2014. http://www.marxists.org/archive/marx/works/1867-c1/.

McDowell, Linda. 1997. Capital Culture: Gender at Work in the City. Malden: Blackwell.Miller, Claire Cain. 2014. Some universities crack code in drawing women to computer science. The New York Times, July 17. Accessed December 2, 2014. http://www.nytimes.com/2014/07/18/upshot/someuniversities-crack-code-in-drawing-women-to-computer-science.html? $\quad r=0 \& a b t=0002 \& a b g=1$.

Miller, Daniel. 2014. NBCUniversal to settle suit by former interns for $\$ 6.4$ million, Los Angeles Times, October 24. Accessed November 17, 2014. http://www.latimes.com/entertainment/envelope/cotown/la-et-ct-nbc-interns-lawsuit-settlement20141024-story.html.

Mills, C. Wright. 1951. White Collar; the American Middle Classes. New York. Oxford University Press. 
Neff, Gina, Elizabeth Wissinger and Sharon Zukin. 2005. Entrepreneurial Labour Among Cultural Producers: "Cool" Jobs in "Hot" Industries. Social Semiotics 15 (3): 307-334.

Oxford English Dictionary. 2014. In Oxford Reference Online, Penn State Library databases. Accessed November 14, 2014.

Pan, Jennifer. 2014. Pink Collar. Jacobin. Accessed May 14, 2015. https://www.jacobinmag.com/2014/06/pink-collar/.

Perlin, Ross. 2012. Intern Nation: How to Earn Nothing and Learn Little in the Brave New Economy. London: Verso Books.

Perry, Mark J. 2008. It's a "Man-Cession" in a Lipstick Economy. Carpe Diem, December 9. Accessed December 2, 2014. http://mjperry.blogspot.com/2008/12/its-man-cession-in-lipstick-economy.html.

Postigo, Hector. 2009. America Online Volunteers: Lessons from an Early Co-Production Community. International Journal of Cultural Studies 12 (5): 451-469.

Rodino-Colocino, Michelle. 2012. "Feminism" as Ideology: Sarah Palin's Anti-feminist Feminism and Ideology Critique. TripleC: Cognition, Communication, Co-operation 10 (2). Accessed June 13, 2014. http://www.triple-c.at/index.php/tripleC/article/viewFile/414/372.

Roediger, David. R. and Elizabeth. D. Esch. 2012. The Production of Difference: Race and the Management of Labour in US History. New York, NY: Oxford University Press.

Rosin, Hanna. 2010. The End of Men. The Atlantic. Accessed June 8, 2015. http://theatlantic.com/magazine/archive/2010/07/the-end-of-men/308135.

Schwartz, Madeleine. 2013. Opportunity Costs: The True Price of Internships. Dissent Magazine: $A$ Quarterly of Politics and Culture. Accessed June 13, 2014. http://www.dissentmagazine.org/article/opportunity-costs-the-true-price-of-internships.

United States Department of Labor. 2010, April. Fact Sheet \#71: Internship Programs under the Fair Labour Standards Act. Accessed October 31, 2014. http://www.dol.gov/whd/regs/compliance/whdfs71.pdf.

United States Department of Labor. 2013. FLSA Coverage-Employment Relationship, Statutory Exclusions, Geographical Limits, Trainees and Student Trainees, Chapter 10, Sectionb11. Field Operations Handbook. Accessed October 27, 2014. http://www.dol.gov/whd/FOH/FOH_Ch10.pdf.

Weissman, Jordan. 2013. Do Unpaid Internships Lead to Jobs? Not for College Students. The Atlantic. Accessed June 13, 2014. http://www.theatlantic.com/business/archive/2013/06/do- unpaidinternships-lead-to-jobs-not-for-college-students/276959/.

Willis, Paul E. 1977. Learning to Labour: How Working Class Kids Get Working Class Jobs. New York: Columbia University Press.

Wissinger, Elizabeth. 2007. Modelling a Way of Life: Immaterial and Affective Labour in the Fashion Modelling Industry. ephemera: theory \& politics in organization 7 (1): 250-269.

\section{About the Authors}

Michelle Rodino-Colocino

Michelle Rodino-Colocino serves as Associate Professor of Media Studies and Women's Studies at Penn State. Her research and teaching interests focus on labour and new media from perspectives spanning critical-cultural and feminist studies. Rodino-Colocino has received awards for her research and teaching and has served on the Steering Committee of Union for Democratic Communications and as program planner for the National Communication Association's Critical and Cultural Studies Division. Her research articles have appeared in Communication and Critical/Cultural Studies; Communication, Culture \& Critique; Critical Studies in Media Communications; New Media \& Society; and Feminist Media Studies, among others.

\section{Stephanie N. Berberick}

A doctoral student in the College of Communications at Penn State, Stephanie "Stevie" Berberick conducts research and teaches in critical-cultural and feminist media studies. Berberick earned her MA from the University at Buffalo (SUNY), where she was awarded a prestigious Arthur A. Schomburg Fellowship. She has published her research in The New York Sociologist and has presented her scholarship around the US and at international conferences. 